\title{
The Citadel of Alessandria: Giuseppe Ignazio Bertola's Architectural Infraction of the Hexagon's Geometrical Regularity
}

\author{
Amelio Fara
}

Published online: 15 November 2014

(C) Kim Williams Books, Turin 2014

\begin{abstract}
The paper focuses on Giuseppe Ignazio Bertola's project for the citadel of Alessandria in Piedmont, Italy, in the eighteenth century. The study is developed analyzing two main aspects: the infraction to the geometry of the regular hexagon, that Bertola adopted for the perimetral form of the citadel, in order to make it more resistant to the external attack on the basis of the orographic context; the conformation to assign to the main enclosure and to the external works on the basis of the specialized treatises published at that time and which Bertola usually referred to.
\end{abstract}

Keywords Military architecture $\cdot$ Alessandria $\cdot$ Piedmont $\cdot$ Eighteenth century · Giuseppe Ignazio Bertola · Geometry · Hexagon

\section{Abbreviations used}

ASTo Archivio di Stato di Torino (State Archives of Turin)

ISCAG Istituto Storico e di Cultura dell'Arma del Genio, Roma

SHAT Service Historique de l'Armée de Terre, Vincennes

\section{Bertola's Sources on the Geometry of the Regular Hexagon}

Giuseppe Ignazio Bertola carried out his study on the fortified regular hexagon grounding it on the treatises by Claude Flamand [1597: ch. VII, 170-173], Donato Rossetti [1678: 198, fig. LII], Allain Manesson Mallet [1684-1685: I, 82-85], Blaise François Pagan [1689: 189-225], Doroteo Alimari [1692: book II, p. 130; 117-118], Jacques Ozanam [1694: p. 23, tav. 2, Fig. 4], Naudin [1695: Bk. III, ch. 2, 196, tav.

\footnotetext{
A. Fara $(\bowtie)$

Florence, Italy

e-mail: amelio.fara@tiscali.it
} 
2, Fig. 3; 199, tav. 3, Fig. 4], Johann Friedrich Pfeffinger [1698: Bk. VI, ch. VII, 212], Menno van Coehoorn [1706: ch. III, 20ff, fig. G, ch. V, 181ff, fig. O], and Abbot Du Fay's interpretation of the treatise by Vauban [1707: 83-88]. This is recorded in his unpublished Dizionario-Repertorio [Bertola 1721: cc. 47r-v, 144v]. ${ }^{1}$

Flamand traced the fortified regular hexagon with second flanks (or curtainflanks), lateral linear protection of bastions, and ravelins without flanks. Rossetti, in the engraving by Giovanni Fayneau, represented it in cavalier perspective with faussebraies, guard-houses, inner buildings, doors, bridges and barriers. The concave flanks of the bastions, ending with a tooth-shape, was a peculiarity of Rossetti's drawing which Bertola surely noticed. Bertola personally supervised the construction of a model of Rossetti's system, restored many times and now held at the ISCAG (Fig. 1), around 1740, when the treatise by Rossetti was held at the Library of the Regie Scuole Teoriche d'Artiglieria e Fortificazione (Fig. 2). Rossetti defined his system of fortification as a rovescio (inside out), because the curved inwards angle of the counterscarp could be found in correspondence to the salient of the bastion. In this system the long flanks of the ravelin-demilune were almost parallel with the capital of the front. The calibrated proportion among the parts is really surprising.

According to the interpretation of Vauban's treatise offered by Abbot Du Fay [1707: 83-88], in the fortified hexagon it is possible to trace on a determinate scale the side 180 toises long, the perpendicular at 1/6 from the middle of the side, the defensive lines going through the ends of the side and the perpendicular, the faces equal to $2 / 7$ of the side on the defensive lines. It is possible to trace an arc that cuts the defensive line with center in the shouldercorner and with radius equal to the distance from the opposite shoulder. The arc string represents the flank of the bastion. It is possible to obtain the curtain by tracing a line from one side to the other. Thus, it is possible to obtain one of the front of the hexagon and, therefore, its magistral line. Bertola, as his father Antonio before him, distanced himself from Vauban's construction technique, although he had studied it; in this respect, his approach was rather different from his contemporary military architects.

The most important text concerning the regular figures for Bertola was the geometric study of the mathematician Hebert who, in 1689, edited the treatise written by Blaise François Pagan, whose first two theorems state:

1. En tous les polygones réguliers, comme tous les costéz sont égaux entre eux, \& les angles du centre semblabes: tous les demi-diamètres sont pareillement égaux, \& les angles du polygone semblables.

2. Si vous divisez le cercle en trois cens soixante degrez par cinq, vous aurez soixante \& douze degrez, pour les angles du centre du pentagone. Et si vous

\footnotetext{
1 The manuscript by Giuseppe Ignazio Bertola entitled Dizi[onario] e repertorio di fortificazione [Bertola 1721], dated October 16th 1721, is held at ASTo, Biblioteca antica, J.b.VI.18. Through the information, in the various items, of "book, chapter and page", I have been able to identify the editions of the treatises quoted by Bertola and, consequently, his reference library in 1721; see [Fara 2014]. Bertola believed that the treatises then assigned to Bernard, Naudin, and Pfeffinger were by anonymous authors.
} 


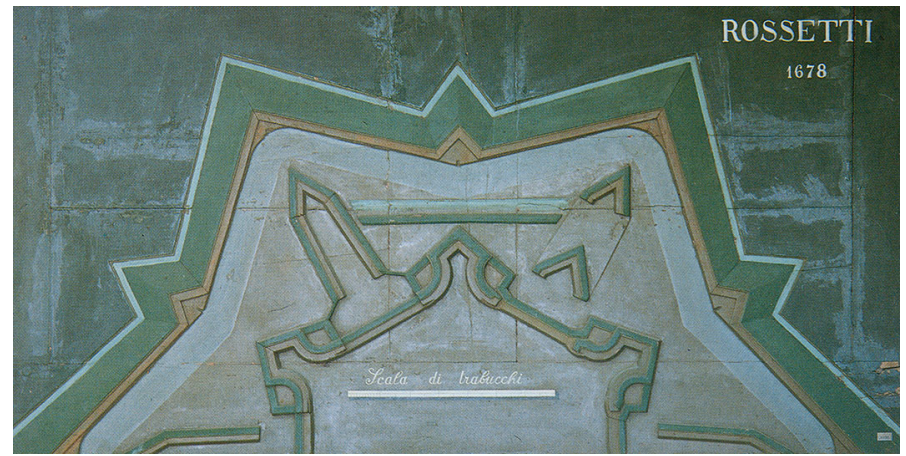

Fig. 1 Giuseppe Ignazio Bertola and collaborator. Wooden model of the fortification system of Donato Rossetti, ca. 1740. Image: ISCAG, inv. 2095

Fig. 2 Frontispiece of Donato Rossetti's treatise (1678) with the hand-written note which states its belonging to the collection of the Library of the "Regie Scuole Teoriche d'Artiglieria e Fortificazione" in 1740. Image: Author's private collection

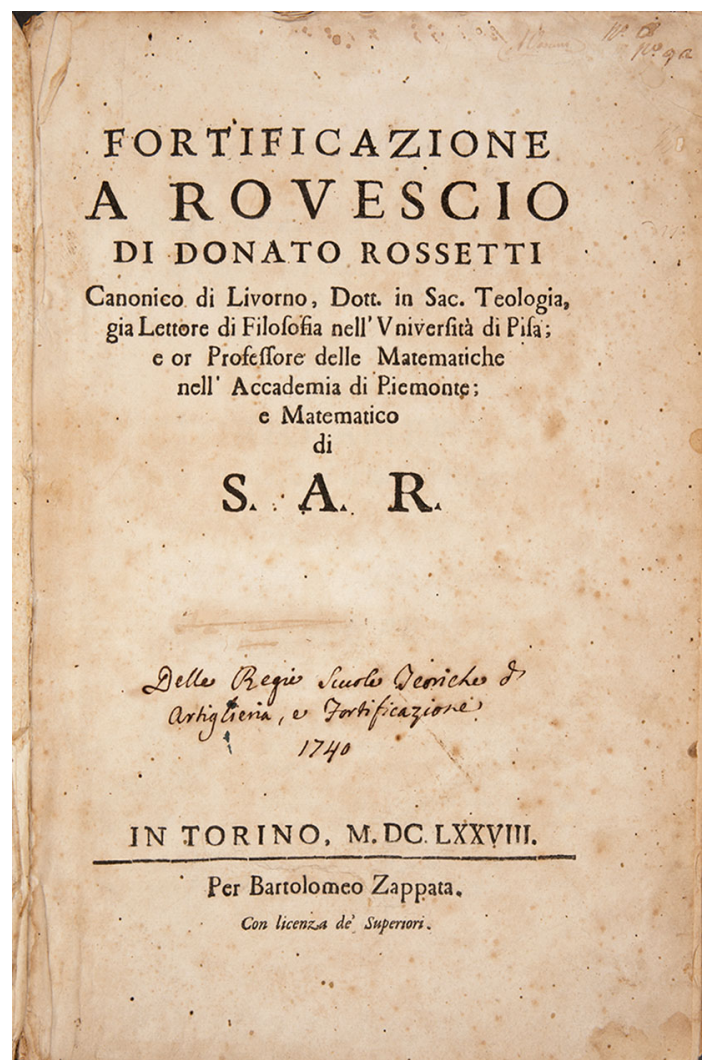

les divisez, par six: vous aurez soixante degrez, pour les angles du centre de l'exagone [Pagan 1689: 189-190].

According to Hebert, the most significant theorems for the geometry of regular polygons were those formulated in paragraphs 18, 34 and 35: 
18. En tout cercle, divisé en quatre parties égales par deux diamètres; si l'un des demi-diamètres est le diamètre d'un cercle décrit, \& l'extremité de l'un des demi-diamètres prochains, le centre d'un autre cercle qui touche le precedent: la ligne droite tirée de l'une à l'autre intersection du premier \& du troisième cercle sera le costé du pentagone inscrit dedans le premier cercle, \& le rayon du troisième cercle, sera le costé du decagone inscrit dans la même Fig.

34. Si vous diviséz la base ou le costé exterieur en deux également, \& que du point du milieu vous éleviez une perpendiculaire, égale à la troisième partie de la moitié de la base, l'extremité de cette ligne perpendiculaire sera le point de l'intersection des deux ligne de deffense.

35. Si des deux extremitez de la base ou costé exterieur du polygone vous tiréz deux lignes droites, qui se coupent sur l'extremité de la precedente perpendiculaire, ces deux lignes droites seront les deux ligne de déffense de vostre fortification regulière [a prescindere dalla perpendicolarità dei fianchi] [Pagan 1689: 194, 198-199].

The reference to Euclid is clear in Hebert's geometric demonstration of these theorems:

Soit décrit du centre $E$, le cercle $A B C D$ : \& les deux diamètres $A C$, \& BD se coupans à angles droits sur le centre. Derechef soit coupé en deux également au point $F$, le semi-diamètre EB: \& du point $F$, soit décrit le second cercle $B G E$, passant sur le centre du premier. Pareillement soit tirée la ligne droite $F C: \&$ du point $C$, soit encore décrit le troisème cercle $N H L$; touchant en $G$, le second cercle BGE. Enfin soit tirée la ligne droite LN. Je dis ensuite que la ligne droite $L N$, est l'un des cinq costéz du pentagone regulier; inscrit dans le premier cercle $A B C D$.

Par la 7 demonstration de mes Remarques, le rayon EC, est coupé en raison extrême \& moyenne; par le segment $\mathrm{CH}$. Et par la 5 \& 9 proposition, du 13 Element de Geometrie LC, égal à $\mathrm{CH}$ [CN]: est le costé du decagone, décrit dans le cercle $A B C D$; puisque EB, est égal au costé de l'exagone, inscrit dans le même; par la quinzième du 4. Mais par la 15 definition du premier des Élemens, CN, est égal à LC. Et par la 29 proposition, du 3 la circonference $L C$, est égale à la circonference CN. Et partant LNC, éstant double de LC: LN, sera le costé du pentagone; inscrit dans le cercle ABCD. Ce qu'il falloit faire voir en faveur du théorème 18 \& de la 10 \& 11 proposition du 4 livre d'Euclide. Parce qu'en tirant dans la même figure, les deux lignes droites $A L$ [EL] \& AN [EN]: vous décrirez dans le cercle $A B C D$, le triangle isocelle $L A N$ [LEN]; don't le côté sera coupé en extrême \& moyenne raison par la base (Fig. 3) [Pagan 1689: 221-223]. ${ }^{2}$

En la presente figure, $B C$, est la base de la fortification régulière, ou le costé exterieur du polygone. DE, est la perpendiculaire; égale à la sixième partie de la base BC. Les deux lignes droites BEM, \& CEL, sont les deux lignes de

\footnotetext{
${ }^{2}$ In the proof, Hebert refers to Euclid's prep. 5 and 9 of Book XIII, prep. 15 of Book IV, prep. 15 of Book I, prep. 29 of Book III, prep. 10 and 11 of Book IV.
} 


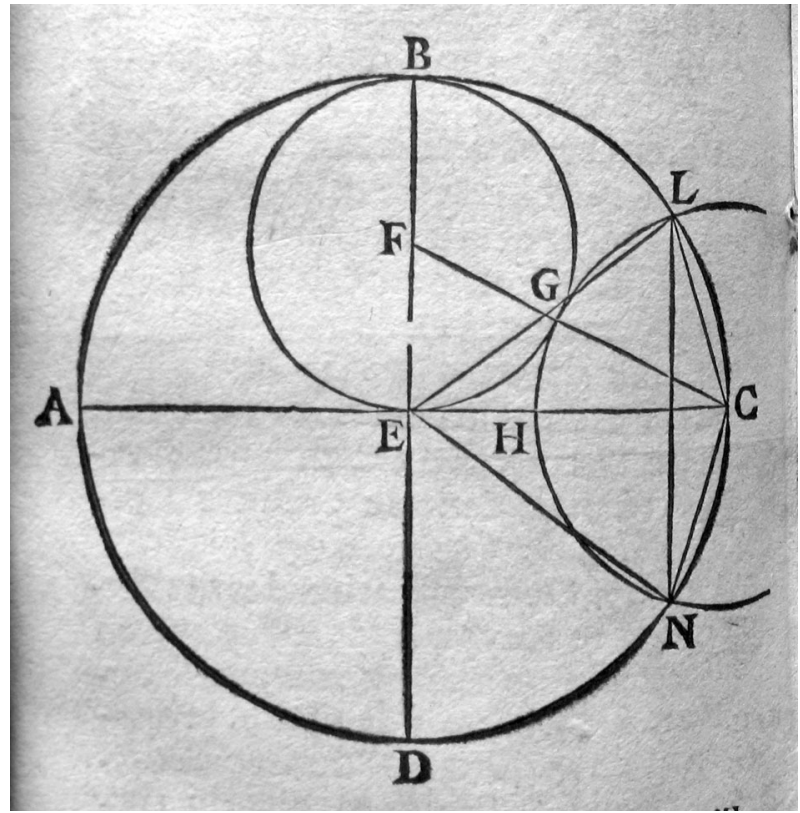

Fig. 3 Hebert, graphical elaboration of the theorem 18 by Earl of Pagan. Image: [Pagan 1689: 222]

défense. $B H \&$ \& $C I$, sont les deux faces des bastions. EF, \& EG, sont les deux complemens des lignes de défense; égaux chacun à la troisième partie de BE ou de CE. FH \& GI, sont les deux flancs élevez perpendiculaires sur les deux lignes de défense $B G \& C F$. FG, est la courtine. FL \& GM, sont les deux prolongemens des lignes de défense. Et BA \& CA, sont les semidiametres $d u$ polygone.

Derechef l'angle BED, est l'angle de la fortification régulière; tûjours égal en tous les polygones. Et les deux angle BCE, \& CBE; sont les angles diminuez; toûjours égaux entr'eux, comme les deux segmens BE, \& CE, par la 4 proposition du premier Élement de Géométrie: parce que $B D$, est égal à $D C: \&$ que ED, est perpendiculaire sur BC. Mais l'angle FEG, éstant égal à l'angle BEC, par la 15 proposition du premier; \& les deux costés EF \& GE, éstans égaux par la construction de la figure: les deux angles EFG \& EGF, sont aussi égaux entre eux \& le triangle FGE, est semblable au triangle BEC, par la première definition du 6 des Élemens. Et par la 4 proposition du même EG, éstant égal à la troisième partie de BE: la courtine GF, sera égale à la troisième partie de la base BC. Comme semblablement les deux angles FGE, \& $E B C$, éstant égaux entre eux par la similitude des mêmes triangles: la même courtine GF, sera parallele à la même base CB, par la 27 proposition $d u$ premier. Ce qu'il falloit démontrer, en faveur des théorèmes 34 \&c. donnéz pour supplément du livre de nos Fortifications (Fig. 4) [Pagan 1689: 223-225]. ${ }^{3}$

\footnotetext{
${ }^{3}$ Reference is made to the prep. 4 of Book I by Euclid, definition of Book VI, prep. 4 of Book VI, prep. 27 of Book I.
} 


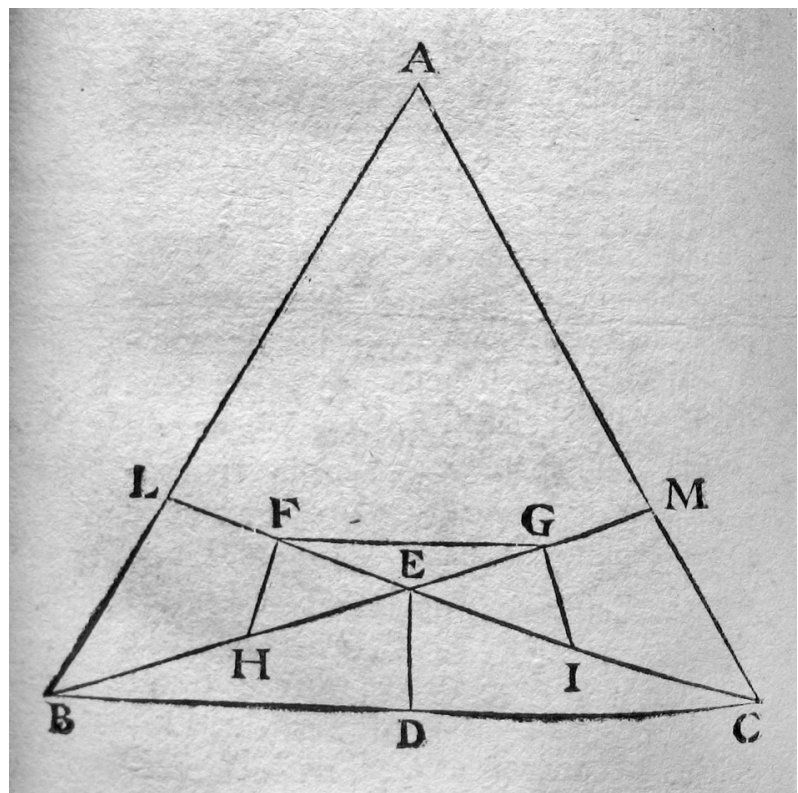

Fig. 4 Hebert, graphical elaboration of the theorems 34 and 35 by Earl of Pagan. Image: [Pagan 1689: 224]

Bertola certainly included the geometric theory of regular polygons in his teaching program on military architecture at the Royal Academy of Turin.

\section{The Irregular Hexagon}

When he devised the polygonal layout for the citadel of Alessandria, a few years after the extensive and detailed study focusing on the geometry of regular figures, Bertola broke the geometric regularity of the hexagon, on the ground of some considerations related to the probable direction of the enemy attack. The choice of Borgoglio instead of the old citadel near the river Bormida as a site on which to build the fortress derived from hydro-geological considerations: in the event of a siege the site of the old citadel, which was bounded between the rivers Tanaro and Bormida and was frequently subjected to floods, would have remained isolated. Even the construction of a possible bridgehead in Borgoglio would have not been sufficient to counteract the advance of besiegers.

The characteristics of Bertola's masterpiece of military architecture in Borgoglio were revealed in an extraordinary document dating from 1761, the Relazione del congresso tenutosi avanti S.E. il signor conte Bogino in cui sono intervenuti $i$ signori commendatore Devincenti, e D'Antoni, signor capitano Soleri e architetto Borra (ASTo, Corte, Materie militari, Intendenza generale delle fabbriche e fortificazioni, mazzo $1 \mathrm{~d}$ 'addizione, n. 27). Concerns related to the need to defend 
the citadel were deeply rooted in the original architectural design. The crushing of the polygon within an oval, implied that both the eastern and western sides $(\mathrm{AB}$ and $\mathrm{DE})$ were 'salient' and that the remaining four sides (BC, CD, AF, FE) formed two by two an angle in the polygon ca. $133^{\circ}$ wide (Fig. 5 ). ${ }^{4}$

This icnographic feature of Bertola's layout would have forced the enemy not to attack the fronts AF and FE; these fronts were considered inapproachable because they skirted alongside the riverbank, unless extensive works on the riverbed were undertaking. The architectural stretching of the hexagon also made the slightly salient fronts BC and CD near the countryside unassailable because the wider angle formed by them would have engendered their defensive interaction, and the enemy would have been forced to attack them both at the same time. This would have implied the use of about two hundred cannons. The attack could only have been possible, with less siege labor, on the salient front AB or DE. The defense project of one of the fronts could therefore serve for the other too, although on the side of the front DE the site presented an easier retreat opportunity for the artillery. The cavaliers of the bastions defended with a higher angle (San Carlo towards the city and Santa Cristina towards the countryside) would have contributed with their fire to the defense of the attacked fronts (AB or DE). Thus, the architectural distribution of the citadel's main door and of the covered fronts doors resulted from the probable direction of the enemy attack. The architectural design of the great engineer and military architect - the greatest of early eighteenth century Europe-was aligned in that direction in both its layout and in its profile.

The original intuition of the attack front was, therefore, the reason for Bertola's architectural breach of the hexagon geometric regularity. The Sardinian military engineers would demonstrate an awareness of that extraordinary project, to the extent that they would use the symbol of the crushed hexagon in the documents held at the Archives of Military Engineers and, similarly, in the ex libris of the treatises which have been merged in the collection of the Military Engineers's Library in Torino.

In an original drawing conserved at the ISCAG (Fortificazioni, 3887 [Fara 1993: Fig. 73; Fara 2006: Fig. 20]), are also represented, among other outworks, the counterguards to the bastions (except in the bastion of Santa Cristina facing the city), the ravelins with flanks in the fronts towards the Tanaro and without flanks (but with counterguards) in the other fronts, the tenailles in front of the curtains (except for those towards the Tanaro, which are, however, supplemented by a linear retrenchment along the river). The capitals of San Carlo (C) and Santa Cristina (F) bastions represent the geometrical symmetry axis of the architecture. Rossetti's teeth, which are absent in the fronts towards the Tanaro, in the other fronts are located where the curtains chain to the concave flanks. The counterguard fronts of the ravelins are on the extension of the bastions counterguard fronts. A late eighteenth-century architectural survey ichnography (Carte topografiche segrete, Alessandria, 25. A. I rosso [Fara 2005: tav. II]), signed by Quaglia, probably

\footnotetext{
${ }^{4}$ In the 1761 document we read: figura esagona [della cittadella] è poco meno che equilatera ed $\grave{e}$ adattata entro un ovale in modo che $i$ soli lati $A B, D E$ sono salienti, e i rimanenti quattro formano di due in due l'angolo del poligono di gradi 133 incirca.
} 


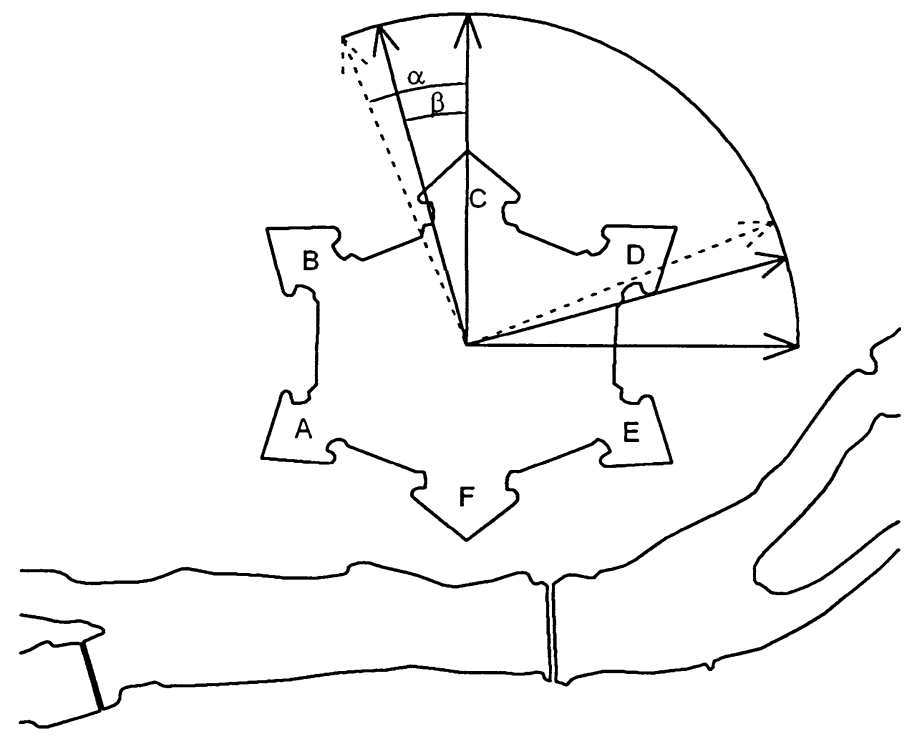

Fig. 5 Letters which identified the bastions of the citadel of Alessandria in the eighteenth century: $A$ San Michele; $B$ San Tommaso; $C$ San Carlo; $D$ Beato Amedeo; $E$ Sant'Antonio; $F$ Santa Cristina. Elaboration of the angular deviation $\alpha$ of the quarters San Tommaso-San Carlo (dashed) in respect to the main axes of the citadel (passing through the bastions capitals of $C$ and $F$ and through the curtains middle points of the western and eastern salient fronts) and of the citadel axes angular deviation $\beta$ in respect to the road-system axes of the pre-existing area of Borgoglio. Image: author

Gaetano, revealed that the faces of the bastions' counterguards were longer than those of the ravelins, unlike the original drawing. Other changes and integrations in the inner buildings and in the outworks were summed up in the ichnographies by Chasseloup-Liédot of 1808 (SHAT, Archives du génie, Article 14 [Fara 2006: Fig. 23]), Agostino Chiodo (BR, O. XIII, 1) of 1846 and in the marble model of the caporal Drivet dating 1852 [Fara 2011: 50, n. 13] (see Fig. 6).

Bertola's design drawing for the citadel aroused more than a few protests. Already on 3 April 1728, a document entitled Parere anonimo, con cui si dimostra doversi prescegliere il sistema dell'ingegnere De Coehorne a quello dell'ingegnere Bertola in ordine ad una nuova invenzione di fortificazione condemned Bertola's 'oblique defense'; it considered inadequate the protection of the faces of the bastions by means of counterguards, and it stated the artillery supremacy of the flanks designed by Coehoorn:

Le sistème donné par $M^{r}$. De Coehorne èstant en lui même le meilleur de tous ceux qui ayent paru jusques à present, et qui se trouve autorisé par les plus habiles ingénieurs de notre temps, me paroit êstre celui sur lequel on peut se régler. En ce que si on examine la construction; on voit que les déffenses ne sont en aucun endroit obliques, mais droites, et quant à l'artillerie il en oppose un aussi grand nombre qu'aucun autre sistème; la rendant superieure en plusieurs endroits, et principalement aux flancs... 


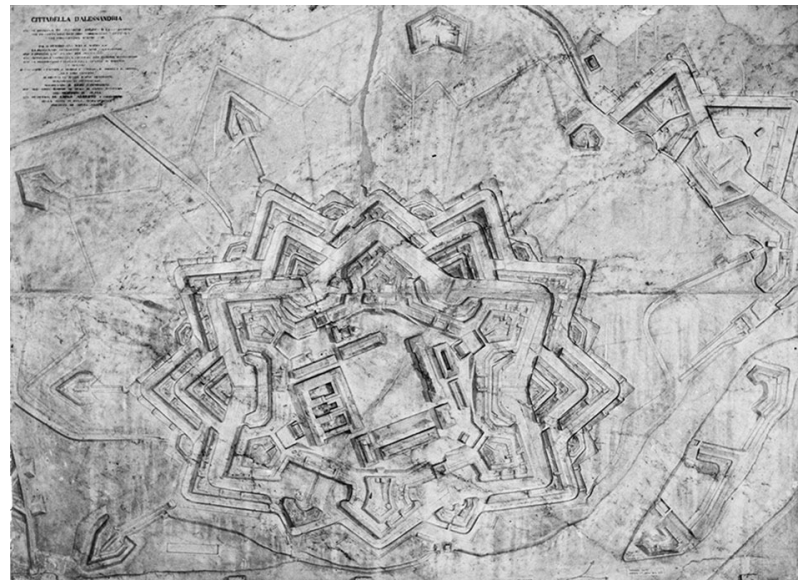

Fig. 6 Drivet, Marble model of the citadel of Alessandria, 1852. Image: ISCAG

le susdit sistème de Coehorn doit êstre preferé à celui de l'ingénieur Bertola; en ce que les gardiens dont ce dernier couvre les faces des bastions, ne me paroissent pas êstre suffisants... [ASTo, Corte, Materie militari, Intendenza generale delle fabbriche e fortificazioni, mazzo 3 inventariato, n. 15].

However, the critical judgment of the anonymous was disregarded and works began according to the project by Bertola who, taking into account the conformation of the site beyond the river Tanaro, created that singular architectural variant of the regular hexagon geometry.

\section{Magistral Line and Outworks}

Giuseppe Ignazio studied the concave flank in the master layout of the royal ${ }^{5}$ hexagon in the treatises by Francesco de' Marchi (Fig. 7), Donato Rossetti, JeanFrançois Bernard (Fig. 8), Naudin, Vauban, Sebastian Fernandez de Medrano. He probably found convincing Bernard's statement:

Le comte de Pagan fait ses flancs retiréz droits comme tous les autres auteurs, \& monsieur de Vauban forme les siens d'un arc, qui est la sixiéme partie d'un cercle. Ces flancs circulaires qui ne le sont point excessivement, valent mieux que les flancs plats; leurs merlons sont plus larges, car il est visible qu'une ligne courbe est plus longue que la droite qui en est la corde; par conséquent ils sont plus forts, \& il y a place pour quelques mousquetaires de plus; il semble que leurs murailles doivent mieux soûtenir l'orillon \& les terres, parce qu'elles forment une espéce de voute.... [Bernard 1689: cap. I, article X, 60-61].

\footnotetext{
5 The adjective "royal" identifies fortifications with superior caliber artillery.
} 


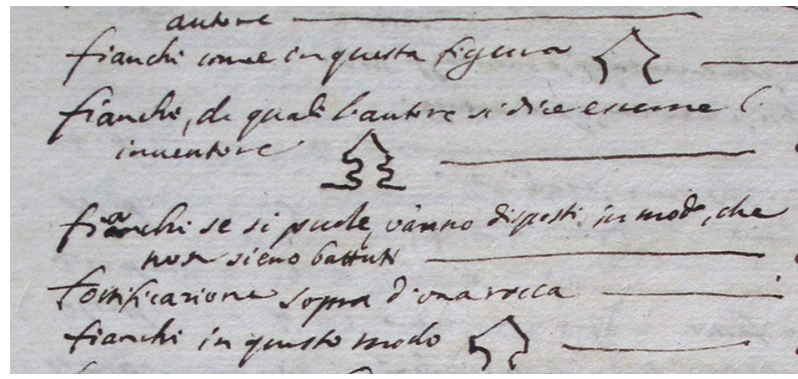

Fig. 7 Giuseppe Ignazio Bertola, Study of flanks, from Francesco de' Marchi (1599). Image: Bertola (1721: c. 62r). By kind permission of ASTo

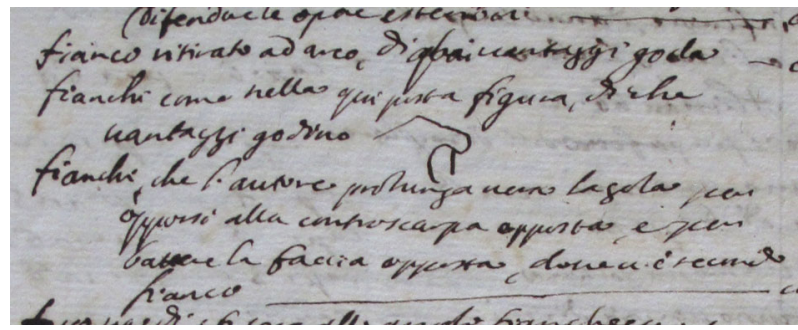

Fig. 8 Giuseppe Ignazio Bertola, Study of a flank, from Jean-François Bernard (1689). Image: Bertola (1721: c. 54r). By kind permission of ASTo

Typical of Bernard, the lengthening of the flanks verso la gola per opporsi alla controscarpa opposta, e per battere la faccia opposta, dove v'è secondo fianco [Bertola 1721: c. 54r] probably confirmed to Bertola the efficiency of Donato Rossetti's stretched flank (see Fig. 1). The shape of the flanks, of the bastions and of the cavaliers in the citadel of Alessandria is almost similar to that of Rossetti and of Coehoorn; and the systems by the latter were assimilated in Bertola's linguistic repertoire [Bertola 1721: c. 56r].

In his repertoire Bertola also focused on the flank perpendicular to the defensive line that the Earl of Pagan had decidedly supported. From another point of view, Ozanam pointed out that the flank $a b$ perpendicular to the grazing defensive line $n e$ tient pas plus de mousquetaires posez obliquement to the flank ed (Fig. 9). Therefore, le flanc ne doit être perpendiculaire ni à la courtine, ni à la ligne de défense, ni à la face du bastion [Ozanam 1694: 10-13, tav. 2, Fig. 8].

Also evident in this huge repertoire is a contrast, engrained in sixteenth- and seventeenth-century European military-architectural culture, which opposed two schools of thought: one that supported the validity of the layout with second flanks and the other that condemned it. Although these theoretical guidelines do not seem to influence the shape of Alessandria's citadel magistral line for the limited length of its fronts, it is necessary to revisit the editions of the treatises which Bertola consulted, noticing that he used second flanks in other works, including the fort of Fenestrelle. 


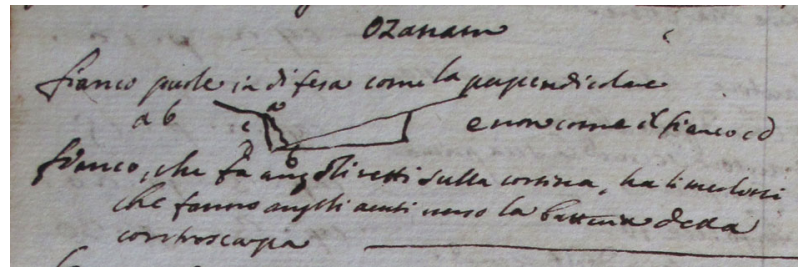

Fig. 9 Giuseppe Ignazio Bertola, Study of a flank perpendicular to the defensive line, from Jacques Ozanam (1694). Image: Bertola (1721: c. 56v). By kind permission of ASTo

Even though the layout with second flanks made it possible to perform the plunging-fire on the opposite salient, it was nevertheless criticized by Charles Theti [1575: Bk. I, ch. VI], Manesson Allain Mallet [1684-1685: Bk. I, ch. III, pp. 51-52, in which he condemned the second flank; II, ch. III, pp. 59-62 in which he considered it], Pagan-Hebert [Pagan 1689: ch.VI], Naudin [1695: 155-156], Vauban-Cambray [Cambray 1689: 96] and Vauban-Du Fay [Du Fay 1707: 109, 114-115]. Pagan considered it useless for the artillery. Naudin stated that the second flanks

que l'on appelle fichans, ou feu de la courtine ne sont point preferable aux flancs razans, \& leur pretenduë avantage, qui est d'augmenter le feu pour défendre la breche et le passage du fossé, est beaucoup moindre que d'avoir des flancs plus longs \& des bastions plus capables [Naudin 1695: 155].

Looking at Vauban's treatise as interpreted by Cavalier De Cambray, the future first director of the Theoretical Schools argued that: il secondo fianco cagiona che le faccie sono battute di rovescio dai fianchi della piazza [Bertola 1721: c. 162r]. Further, in the interpretation by Abbot Du Fay of Vauban's treatise we read that:

Errard, Stevin, Sardi [?], Pagan, \& quelques autres ne veulent point de second flanc. Marolois, Fritach, Dögen, \& de Ville, veulent un second flanc, ou feu de courtine. L'expérience a fait connoître que le flanc formé par la corde d'un segment, qui a pour centre l'épaule du bastion opposé, est le meilleur de tous. Les coups qu'on en tire sont droits, le service du canon en est facile, \& le mousqutaire n'est point gêné. C'est le flanc de monsieur de Vauban [Du Fay 1707: 114-115].

Otherwise, in Bertola's linguistic analysis of the treatises Francesco de' Marchi [1599: Bk. II, ch. IX, c. 19; Bk. III, ch. CXXVI, c. 190], Buonaiuto Lorini [1609: Bk. I, ch. I, 9], Adam Freitag [1635: Bk II, ch. II, 77], Pietro Sardi [1639: Bk. II, 69], Antoine de Ville [1640: Pt. I, ch. XXI, 55], Matthias Dögen [1648: Bk. I, ch. II, 17: some engineers ont tiré la ligne flancquante, qui défend le bastion, non de l'angle où poinct commun au flancq \& à la courtine, mais d'un autre, avançant davantage dedans la courtine: i.e. me tiens à ces derniers, \& quitte volontiers les autres ...; Bk. I, ch. V, 36; Bk.II, ch. IV, 241], Georges Fournier [1668: Bk. I, ch. I], Silvère de Bitainvieu [1674: Treatise I, 38], Guarino Guarini [1676: passim], Annibale Porroni [1676: Bk. II, ch. XXII, 140-141], Claude-François Milliet Dechales [1677: Bk. I, 


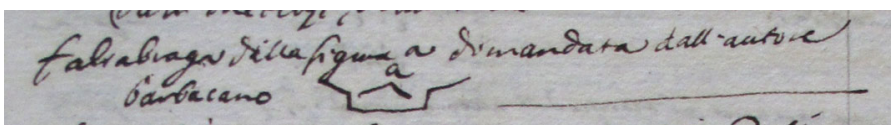

Fig. 10 Giuseppe Ignazio Bertola, Study of a faussebraie-barbicane, from Francesco de' Marchi (1599). Image: Bertola (1721: c. 62r). By kind permission of ASTo

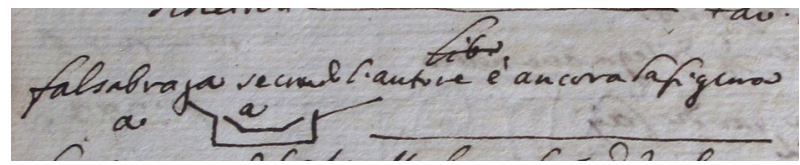

Fig. 11 Giuseppe Ignazio Bertola, Study of a faussebraie, from M*** [Pfeffinger] (1698). Image: Bertola (1721: c. 55v). By kind permission of ASTo

prop. 17, 48; Bk. IV, 271], Donato Rossetti [1678, 189-190, fig. XLVII], JeanFrançois Bernard [Bernard 1689: ch. I, article I, 1-31; article VIII, 53-54; ch. V, article I, 228] and Johann Friedrich Pfeffinger [1698: ch. VII, 147] seemed totally or partially convinced of the second flanks.

Bertola derived from Bitainvieu the opinion that the second-flank è più vicino del fuoco del fianco per battere la faccia [Bertola 1721: c. 58]; from Freitag that ha di vantaggio, che le due faccie si difendano meglio l'una con l'altra [Bertola 1721: c. $62 \mathrm{v}]$. Furthermore, from Dögen, that the same second-flank represents the main element of a fortress, although it could be alle volte pernicioso [Bertola 1721: c. 64r]; from Guarini, that you should never leave it defenceless; from Bernard-who had defended it contro messieur de Pagan-that it is not advisable praticarsi quando cagiona diminuzione del fianco principale [Bertola: cc. 162r-v]; from Pfeffinger, that deve praticarsi, quando non è dannoso alle altre parti della fortezza [Bertola: c. 162v]. Probably through Dechales, Bertola increased his awareness, mirrored in the design of Alessandria's citadel, of the difficulty de donner une défense fichante aux angles [in figure], qui ont moins de cent vingt degrez, si ce n'est que les costez soient extraordinairement grands [Dechales 1677: Bk. IV: 271].

Among the outworks of Giuseppe Ignazio's citadel, it is necessary to focus on the tenaille. In the repertoire, he studied the faussebraie-barbicane by Francesco de' Marchi (Fig. 10) and the faussebraie-tenaille illustrated by Pfeffinger [Bertola 1721: c. 55v] (Fig. 11).

It is necessary to go back to the faussebraie by Pietro Paolo Floriani (1630), then re-elaborated by Rossetti (see Fig. 1) and by Coehoorn, who defined it cortina bassa, low curtain [Coehoorn 1707: ch. II, 12]. Bertola also learned from Francesco Tensini that from the faussebraie-barbican se bene la cortina è longa, si difende anche con la moschetteria la faccia de' balloardi [Tensini 1624: Bk. I, ch. XI, 24, tav. 2; ch. XXII (treatise on the faussebraie and the barbicane) 49-51, tav. 10]; and that è opera moderna, la quale bensì puol essere stata fatta ad imitazione della barbacana degli antichi [Bertola 1721: c. 65v]. However, the tenailles that most directly influenced Bertola's project for the citadel of Alessandria were those 


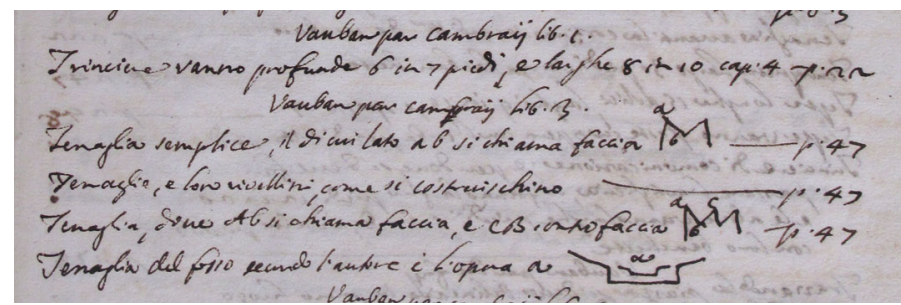

Fig. 12 Giuseppe Ignazio Bertola, Study of a tenaille by Vauban, from Vauban-Cambray (1689). Image: Bertola (1721: c. 168r). By kind permission of ASTo

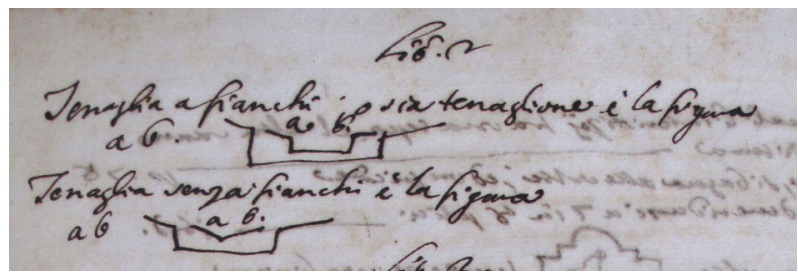

Fig. 13 Giuseppe Ignazio Bertola, Study of Vauban's tenaille with and without flanks, from $\mathrm{M}^{* * *}$ [Pfeffinger] (1698). Image: Bertola (1721: c. 169r). By kind permission of ASTo

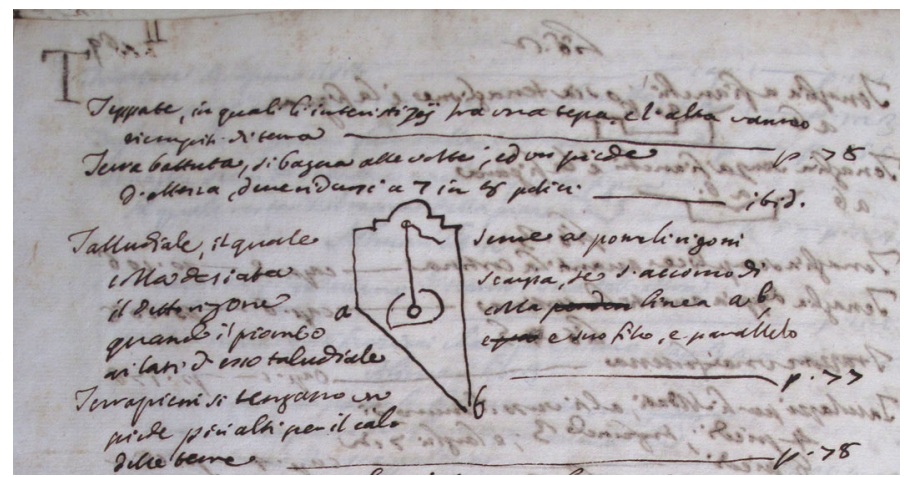

Fig. 14 Giuseppe Ignazio Bertola, 'Talludiale'. Construction- tool used to build a rampart. Image: Bertola (1721: c. 169v). By kind permission of ASTo

designed by Vauban, which were located in the ditch in front of the curtain [Bertola 1721: cc. 168r, 169r] (Figs. 12-13). ${ }^{6}$

The construction of the scarp slope in the elevation of the ramparts of the magistral line and of the outworks (tenailles, ravelins, counterguards) was made possible by the use of a tool which Bertola called 'talludiale' (from talud), il quale

\footnotetext{
${ }^{6}$ For the tenailles, see [Cambray 1689: nouveau traité des fortifications, Bk. III, 47]; [Pfeffinger 1698: Bk. II]; [Naudin 1695: Bk. III, ch. V, 222-224, 226]. Among the outworks of the citadel of Alessandria there were also those made by the French during the Napoleonic period [Fara 2006: 50-64] and by the Sardinian military engineers [Fara 2011: 45-59].
} 
serve a porre li rigoni alla desiata scarpa, se s'accomodi il detto rigone alla linea ab, quando il piombo e suo filo, è parallelo ai lati d'esso talludiale [BERTOLA 1721: c. 169v] (Fig. 14). This tool was introduced in his treatise by Jacques Ozanam, who called it niveau or plomb [Ozanam 1694: 78, tav. 9, Fig. 26].

Translated from the Italian by Laura Blandino

\section{References}

Alimari, Doroteo. 1692. Instruttioni militari appropriate all'uso moderno di guerreggiare. Opera nuova utile, e necessaria a' professori dell'onorata disciplina della militia, divisa in tre libri. Nuremberg [Venezia]: Girolamo Albrizzi.

Bertola, Giuseppe Ignazio. 1721. Dizi[onario] e repertorio di fortificazione. Dove in ogni cosa a tal scienza appartenente si citano le opinioni delli più celebri Autori, che sino a' nostri tempi abbino scritto sopra dell'Arte di fortificare, attaccare, e difendere. Opera utile a chi si dà allo studio militare; potendosi con questa ritrovare subito ciò che da circa cinquant'Autori sia stato creduto utile, o svantaggioso in riguardo delle cose spettanti alle fortificazioni. Si aggiunge, che chi avrà gli Autori citati, o parte di essi, potrà senza fatica, e lunga lettura ritrovare le diverse costruzioni dei differenti modi di fortificare tanto rispetto del corpo della Piazza, che delle opere esteriori; e d'ogni altra cosa; mercè che per alfabetto in questo libro si ritrova la parola proposta; e poi sott'ad ogni respettivo Autore si vede il di lui sentimento con citazione del libro, capo, e pagina. Dated October, 16th 1721, ASTo, Biblioteca antica, J.b.VI.18.

[Bernard, Jean-François]. 1689. Nouvelle manière de fortifier les places, tirée des methodes du chevalier de Ville, du comte de Pagan,et de monsieurde Vauban. Avec des remarques sur l'ordre renforcé, sur les desseins du capitaine Marchi, et sur ceux de M. Blondel, suivies de deux nouveaux desseins. Paris: Estienne Michallet.

Bitainvieu, Silvère de [Jean Du Breuil]. 1674. L'art universel des fortifications, françoises, holandoises, espagnoles, italiennes, et composées. Avec l'art d'attaquer les places fortifiées par les surprises \& par la force, \& aussi de defendre les places fortifiées contre les surprises \& contre la force. Paris: Jacques Du Breuil. Third corrected and improved edition. (First edition 1665).

Cambray, Chevalier de. 1689. Manière de fortifier de $M^{r}$ de Vauban. Où l'on voit de quelle méthode on se sert aujourd'hui en France, pour la fortification des places tant régulieres qu'irrégulieres; en quoi cette method differe des autres, \&c. Avec un traité de geometrie qu'en a mis à la tête, pour avoir une parfait intelligence des fortifications. Amsterdam: Pierre Mortier.

Coehoorn, Menno van. 1706. Nouvelle fortification, tant par un terrain bas et humide, que sec et élevé, representée en trois manières sur le contenu intérieur de l'exagone à la françoise, où l'on fait voir quelle est la force des fossez secs moderns, \& de ceux qui sont pleins d'eau. Avec une method modern de fortifier les places maritimes, aussi-bien que celles qui sont situées sur le bord des rivières, et comment elle doivent être bâties. Comme aussi l'attaque de chaque méthode comparée tant en sa force particuliere, qu'en sa dépense, à la pratique de fortifier les places à la françoises. La Haye: Henry van Bulderen. First French edition. (The original Flemish edition is dated 1685).

Dechales, Claude-François Milliet. 1677. L'art de fortifier, de defendre, et d'attaquer les places, suivant les methodes françoises, hollandoises, italiennes \& espagnoles. Le tout enrichy de figures en taille douce. Paris: Estienne Michallet. (Previously published in 1674 in Cursus seu mundus mathematicus).

De' Marchi, Francesco. 1599. Architettura militare, del capitano Francesco de' Marchi bolognese, gentil'huomo romano, libri tre. Brescia: appresso Comino Presegni, ad instanza di Gasparo dall'Oglio. Posthumous edition.

de Ville, Antoine. 1640. Les fortifications du chevalier Antoine de Ville, contenans la maniere de fortifier toute sorte de places tant regulierement, qu'irregulierement en quelle assiete qu'elles soient; comme aussi les ponts, passages, entrées de rivieres, port de mer: la construction de toutes sortes de forts \& citadelles; le moyen facile de tracer sur le terrain. Le tout à la moderne, comme il se practique dans la meilleures places de l'Europe, demontré \& calculé par les sinus \& logarithmes. Avec l'ataque, et les moyens de prendre les places par intelligence, sedition, surprise, stratageme, escalade: les 
effects de diverses sortes de petards, pour faire sauter les portes, murailles \& bastimens: plusieurs instrumens pour rompre les chaines \& paux: l'ordre des longs sieges, la construction des forts, \& redoutes, les retranchemens des quartiers. Des tranchées, bateries, mines, \& plusieurs inventions nouvelles non iamais escrites. Puis la defense, \& l'instruction generale pour s'empescher des surprises: les remedes contre la trahison, sedition, revolte: pour se garantir des escalades: diverses intentions nouvelles contre le petard: la defense contre le longs sieges, \& contre les sieges par force: l'ordre contre les aproches: des sorties, contre-mines, retranchemens, capitulation, \& reddition des places. Le tout representé en cinquante-cinq planches, avec leurs plantes, prospective, \& paisages. Le discours est prevue par demonstrations, experiences, raisons communes, \& physiques, avec les rapports des histories anciennes, \& moderns. Lione: Philippe Borde. (1641 in the frontispiece; first edition 1628).

Dögen, Matthias. 1648. L'architecture militaire moderne ou fortification: confirmée par diverses histoires tant anciennes que nouvelles, \& enrichie des figures des principales forteresses qui sont en l'Europe. Amsterdam: Louys Elzevier. First French edition. (First edition 1647).

Du Fay. 1707. Manière de fortifier selon la methode de monsieur de Vauban, avec un traté préliminaire des principes de geométrie. Paris: Jean Baptiste Coignard. (First edition 1681).

Fara, Amelio. 1993. La città da guerra nell'Europa moderna. Torino: Einaudi.

Fara, Amelio. 2006. Napoleone architetto nelle città della guerra in Italia. Firenze: Olschki.

Fara, Amelio. 2011. Luigi Federico Menabrea (1809-1896). Scienza, ingegneria e architettura militare dal regno di Sardegna al Regno d'Italia. Firenze: Olschki.

Fara, Amelio. 2014. L'arte della scienza. Architettura e cultura militare a Torino e nello Stato Sabaudo 1673-1859. Firenze: Olschki.

Flamand, Claude. 1597. La guide des fortifications et conduite militaire, où sont contenus sept livres de mathematique, \& geometrie, contenant ce qu'est le plus necessaire, pour l'utilité de la vie humaine. Montbeliard: Iaques Foillet.

Floriani, Pietro Paolo. 1654. Difesa et offesa delle piazze di Pietro Paolo Floriani da Macerata. Opera non solo utile, e necessaria a' capitani, e governatori di fortezze, ma anco di sommo profitto a' studiosi dell'historie militari, cosi antiche, come moderne. Venezia: Francesco Baba. Second edition. (First edition 1630).

Fournier, Georges. 1668. Traité des fortifications, ou architecture militaire, tirée des places les plus estimées de ce tmps, pour leurs fortifications. Divisé en deux parties. La première vous met en main les plans, coupes, \& élévations de quantité de places fort estimées, \& tenuës pour très-bien fortifiées. La seconde vous fournir des pratiques faciles pour en faire de semblabes. Second edition. Amsterdam : Jean Jansson a Waesberge et la vefve du feu Elize a Veyerstraet.

Freitag, Adam. 1635. L'architecture militaire ou la fortification nouvelle, augmentée et enrichie de forteresses regulieres, irregulieres, et de de hors; le tout a la practique moderne. Leida: Elzeviers. First French edition. (First edition 1631).

Guarini, Guarino. 1676. Trattato di fortificatione, che hora si usa in Fiandra, Francia, \& Italia. Torino: Heredi di Carlo Gianelli.

Lorini, Buonaiuto. 1609. Le fortificazioni di Buonaiuto Lorini, nobile fiorentino. Nuovamente ristampate, corrette \& ampliate di tutto quello che mancava per la lor compita perfettione, con l'aggiunta del sesto libro. Dove si mostra, con la scienza, e con la pratica, l'ordine di fortificare le città, e altri luoghi, con tutti gli avvertimenti, che più possono apportar beneficio, per la sicurtà delle fortezze, cioè, nel primo libro. Si tratta della scienza d'intorno alle regole da formare le piante delle fortezze, con le sue misure. Nel secondo. Si mostra la pratica con la quale si debbe fabricare la fortezza in opera reale. Nel terzo. Si descrivono le diversità delle piante, con l'elettione delle miglior difese. Nel quarto. Si dichiara la diversità de' siti, \& come si debbono fortificare. Nel quinto. Si tratta delle scienze mecaniche, \& l'ordine facilissimo del fabricare tutti gli strumenti \& machine artificiose che possono fare di bisogno, sì in tempo di pace come di guerra, e come si possano con poca forza dominare grandissimi paesi. Nel sesto, e ultimo. Si tratta della difesa delle fortezze, \& si mostrano tutti quegli avvertimenti, \& inventioni, con le quali i difensori si possono difendere, con quel maggior vantaggio, che si può desiderare, per la sicurtà della fortezza; \& oltre ciò si mostra l'ordine del misurare le distanze \& levar le piante, con altri particolari necessari per effettuare quanto s'è proposto. Venezia: Francesco Rampazetto. Reviewed and improved edition from the sixth book. (First edition 1596).

Manesson Mallet, Allain. 1685. Les travaux de Mars, ou l'art de la guerre. Divisé en trois parties. La premiere, enseigne la methode de fortifier toutes sortes de places regulieres \& irregulieres. La seconde, explique leurs constructions, selon les plus fameux auteurs, qui en ont traité jusqu'à 
present, \& donne aussi la maniere de les bâtir. La troisème, enseigne les fonctions de la cavalerie \& de l'infanterie, traite de l'artillerie, \& donne la methode d'attaquer \& de deffendre les places. Avec un ample détail de la milice des turcs, tant pour l'attaque que pour la deffence. Ouvrage enrichi de plus de quatre cens planches gravées en taille-douce. I. Paris: Denys Thierry.

Manesson Mallet, Allain.1684. Les travaux de Mars, ou l'art de la guerre. Tome second. Contenant la maniere de costruire \& de fortifier toutes sortes de villes \& de places; selon toutes les diverses manieres qui ont esté inventées jusqu'à present par les plus sçavants auteurs, \& les plus fameux ingenieurs qui ont traitté de cette science: comme Errard, Marolois, Fritach, Stevin, Dogen, Marchi, Sardi, De Ville, le comte de Pagan \& autres. Avec des remarques sur les avantages \& les desavantages de leurs methodes; \& le parallele de leurs constructions avec celle de l'auteur, \& d'amples dissertations pour \& contre l'usage des cazemates, des fausses-brayes, \& des seconds flancs: ensemble les raisons de l'auteur, pour les flancs \& les cazemates de ses places. II. Paris: Denys Thierry.

Manesson Mallet, Allain. 1684. Les travaux de Mars, ou l'art de la guerre. Tome troisième. Contenant les noms, charges \& devoirs des officiers d'infanterie, de cavalerie \& d'artillerie. Des evolutions nouvelles. De l'artillerie, \& composition des poudres, avec celle de toute sorte de feux d'artifices. Des instruments qui servent, ou à la defense, ou à l'attaque des places, villes \& châteaux. De la marche \& conduit des troupes \& armées. Du campement pour les sieges; \& de l'attaque des places, villes \& châteaux. De la defence des places, contre toutes sortes de sieges \& d'attaques. De la capitulation \& reddition des places. De la milice des turcs, de leur maniere de faire la guerre, d'attaquer, \& de défendre les places. III. Paris: Denys Thierry. Edition 1684-85. (First edition 1671-1672).

Naudin. 1695. L'ingenieur François, contenant la geometrie pratique sur le papier \& sur le terrain, avec le toisé des travaux \& des bois; la fortification reguliere \& irreguliere; sa construction effective; l'attaque \& la défense des places. Avec la methode de monsieur de Vauban, \& l'explication de son nouveau systeme. Paris: Estienne Michallet.

Ozanam, Jacques. 1694. Traité de fortification, contenant les methodes anciennes \& modernes pour la construction \& la deffense des places, et la maniere de les attaquer, expliquée plus au long qu'elle n'a été jusques à present. Paris: Jean Jombert.

Pagan, Blaise François. 1689. Les fortifications du comte de Pagan, nouvelle edition. Augmentée d'une Idée generale de la fortifications; où les termes de cét Art sont expliqués \& rapports à de nouvelles Figures: avec des notes sur le texte. Et des Eclaircissemens qui contiennent la solution des principales difficultez qu'il y ait dans cette Science: et la maniere de fortifier de monsieur de Vauban. ed. Hebert. Paris: Nicolas Langlois. (First edition of the Fortitications 1645; first edition of the Theorems 1674).

Pfeffinger, Johann Friedrich. 1698. Nouvelle fortification françoise, espagnole, italienne \& hollandoise ou Recueil de differentes manieres de fortifier en Europe. Amsterdam: George Gallet.

Porroni, Annibale. 1676. Trattato universale militare moderno del marchese Annibale Porroni general maggiore del regno di Polonia, diviso in sei libri. Venezia: Francesco Nicolini.

Rossetti, Donato. 1678. Fortificazione a rovescio di Donato Rossetti canonico di Livorno, dott. in sac. teologia, già lettore di filosofia nell'università di Pisa; e or professore delle matematiche nell'Accademia di Piemonte: e matematico di S.A.R.. Torino: Bartolomeo Zappata.

Sardi, Pietro. 1639. Corno dogale della architettura militare. Venezia: I Giunti.

Tensini, Francesco. 1624. La frortificatione guardia difesa et espugnazione delle fortezze esperimentata in diverse guerre. Venezia.

Theti, Carlo. 1575. Discorsi delle fortificazioni, del sig. Carlo Tetti. Ove diffusamente si dimostra, quali debbano essere $i$ siti delle fortezze, le forme, $i$ recinti, fossi, baloardi, castelli \& altre cose a loro appartenenti, con le figure di esse. Hora di nuovo da lui medesimo ricorretti, e ampliati del secondo libro. Con gli elenchi di tutti i capitoli; \& tavola di tutte le materie, che in essi si trattano. Venezia: Bolognino Zaltiero. Improved edition - with a second book- in respect to the first edition (1569).

Theti, Carlo. 1589. Discorsi delle fortificazioni, espugnazioni, \& difese delle città, \& d'altri luoghi. Di Carlo Tethi. Divisi in libri otto. Ove diffusamente si dimostra, quali debbano essere $i$ siti delle fortezze, le forme, i recinti, fossi, baloardi, castelli, e altre cose a loro appartenenti, con le figure di esse. Hora di nuovo da lui medesimo ricorretti, \& ampliati. Con gli elenchi di tutti $i$ capitoli; $e$ tavola di tutte le materie, che in essi si trattano. Venezia: Francesco de Franceschi. 
Amelio Fara engineer and architect, is one of the most important European researchers of military architecture. His wide scientific production includes the famous essay entitled La città da Guerra nell'Europa moderna (Torino, Einaudi, 1993). Another important field of research of the author is the history of civil architecture: he has written essays on Michelangelo, Bernardo Buontalenti, Francesco Borromini and Guarino Guarini. In 1996 at Casa Buonarroti he discovered a previously unknown drawing by Michelangelo, illustrating the project for the church of the Nazione Fiorentina in Rome; recently, he has published the books Napoleone architetto nelle città della guerra in Italia (Firenze, Olschki, 2006), "L'arte vinse la natura". Buontalenti e il disegno di architettura da Michelangelo a Guarini (Firenze, Olschki, 2010), Luigi Federico Menabrea (1809-1896). Scienza, ingegneria e architettura militare dal Regno di Sardegna al Regno d'Italia (Firenze, Olschki, 2011) and L'arte della scienza. Architettura e cultura militare a Torino e nello Stato Sabaudo 1673-1859 (Firenze, Olschki, 2014). 